\title{
ISOLATION OF HIGH QUALITY TOTAL RNA FROM VARIOUS TISSUES OF OIL PALM (Elaeis guineensis) FOR REVERSE TRANSCRIPTION QUANTITATIVE REAL-TIME PCR (RT-qPCR)
}

\author{
ONG, P W*; CHAN, P-L*; OOI, L C L* and SINGH, R*
}

\begin{abstract}
The extraction of high quality total ribonucleic acid (RNA) has become an essential step for downstream plant molecular biology research. In oil palm, several total RNA extraction protocols have been reported across specific tissues using either conventional method or commercial kits. To our knowledge, there is no specific total RNA extraction method described for oil palm whole fruit which contains lipids, polysaccharides, protein, polyphenols and other secondary metabolites. Here, a modified cetyltrimethylammonium bromidelithium chloride (CTAB-LiCl) method with addition of phenol was established to extract total RNA across various oil palm tissues, especially for whole fruit at eight weeks after an thesis (WAA) and 15 WAA. To assess the extracted total RNA, quality and quantity as well as integrity were evaluated using spectrophotometer and bioanalyser, respectively. It was found that modified CTAB-LiCl method with addition of phenol was able to produce good quality (both $A_{260} / A_{280}$ and $A_{260} / A_{230}$ ratios $>1.8$ ) and intact (RIN > 7.4) total RNA. Furthermore, reverse transcription quantitative real-time polymerase chain reaction (RT-qPCR) was successfully performed across all total RNA extracted using two reference genes (PD00569 and pOPEA01332) and one gene of interest, ethylene-responsive transcription factor-3 like, designated as PD00088. The results indicated that the method is suitable for extraction of total RNA from whole fruit as well as other oil palm tissues and is amenable to RT-qPCR.
\end{abstract}

\section{Keywords: whole fruit, total RNA extraction, modified CTAB, gene expression, RT-qPCR.}

Date received: 11 October 2018; Sent for revision: 12 October 2018; Received in final form: 11 February 2019; Accepted: 17 February 2019.

\section{INTRODUCTION}

Oil palm (Elaeis guineensis) is one of the important oil crops worldwide. It is a tropical perennial oil crop that can produce palm oil from mesocarp and palm kernel oil from kernel. Palm oil is mainly used for edible purposes, while palm kernel oil has industrial application (Sambanthamurthi et al., 2000; Kushairi et al., 2018). Due to its growing economic importance,

Malaysian Palm Oil Board, 6 Persiaran Institusi,

Bandar Baru Bangi, 43000 Kajang, Selangor, Malaysia.

E-mail:chanpl@mpob.gov.my extensive research has focused on elucidating the underlying molecular mechanism associated with oil synthesis during fruit development (Tranbarger et al., 2011; Umi et al., 2012; Dussert et al., 2013; Wong et al., 2014; Jin et al., 2017). In order to study molecular regulation during these development processes, ribonucleic acid (RNA) extraction is the necessary first step. High quality total RNA is essential for cDNA synthesis in gene expression studies such as reverse transcription quantitative real-time polymerase chain reaction (RT-qPCR), northern blot, in situ hybridisation, DNA microarray and next generation transcriptome sequencing. 
However, extracting high quality total RNA from oil palm fruit is difficult due to the presence of lipids, polysaccharides, protein, polyphenols and other secondary metabolites (Kok et al., 2013). Whole fruit tissues of oil palm comprise of epicarp, mesocarp, endocarp and kernel (endosperm and embryo). Moreover, these tissues contain different levels of biochemical composition during the various stages of development particularly at the maturity stage. Oil deposition in mesocarp and kernel start at approximately 15 to 20 weeks after anthesis (WAA) and 12 to 16 WAA, respectively (Sambanthamurthi et al., 2000). Large amount of lipids often found in whole fruit at this stage can co-precipitate with total RNA, thus restricting its yields and deteriorating the quality. In recent years, several conventional total RNA extraction methods including sodium dodecyl sulphate (SDS) (Low et al., 2009; Shaharuddin and Parveez, 2003), cetyltrimethylammonium bromide (CTAB) (Laksana and Chanprame, 2015) and commercial RNA extraction kits such as iNtRON Biotechnology (Habib et al., 2014) and Qiagen (Amanda and Cartealy, 2015; Chai et al., 2016) have been successfully used to extract total RNA from different oil palm tissues such as vegetative (leaf and root), reproductive (fruit and flower) as well as tissue culture materials (embryogenic callus, nonembryogenic callus and embryoid). However, the extraction of total RNA from oil palm fruits had only been carried out separately on the mesocarp and/or kernel (Shaharuddin and Parveez, 2003; Low et al., 2009; Amanda and Cartealy, 2015). To our knowledge, no work has been done thus far to extract the total RNA from whole fruit without separating the mesocarp and kernel.

Methods involving $\mathrm{CTAB}$ were mainly developed for total RNA extraction from a wide range of plant tissues containing high level of polysaccharides and secondary metabolites in pine (Chang et al., 1993), peach (Tong et al., 2012) and tea (Muoki et al., 2012). This method was also used for extracting total RNA from lipid-rich tissues such as jatropha seed (Sangha et al., 2010) and avocado fruit (Djami-Tchatchou and Straker, 2012). The method was able to extract high quality total RNA from specific plant species with different content of polysaccharides and lipids. Therefore, it would be the most reliable and efficient method for extracting total RNA from the whole fruit of oil palm.

For an accurate quantification of gene expression using RT-qPCR, high quality total RNA must be used for cDNA synthesis. The RT-qPCR is one of the common and powerful methods for the study of gene expression. It has become the preferred choice for quantifying genes of interest (GOI) in plant research, due to its high sensitivity, specificity, accuracy, repeatability and reproducibility (Gachon et al., 2004; Bustin et al., 2009). Prior to evaluating expression patterns in different tissues or at different developmental stages, it is important to ensure that high quality total RNA is being used for cDNA synthesis (Bustin and Nolan, 2004; Fleige and Pfaffl, 2006). Therefore, the quality and purity of the total RNA is very important for accurate quantification of the gene expression.

In this study, a modified CTAB-lithium chloride $(\mathrm{LiCl})$ method with addition of phenol was developed to extract high quality total RNA from various oil palm tissues including leaf, inflorescence, root, mesocarp and kernel at two developmental stages (8 and $15 \mathrm{WAA}$ ) as well as whole fruit. Downstream application of the extracted total RNA was evaluated using RT-qPCR by investigating the expression profile of ethyleneresponsive transcription factor-3 like (PD00088) gene in these tissues. The PD00088 was the obvious choice as the gene had been tested successfully for association with somatic embryogenesis in oil palm (Chan et al., 2014). However, the expression profiles across vegetative tissues were only determined for the first time in this study.

\section{MATERIALS AND METHODS}

\section{Plant Materials}

All the oil palm tissues were collected from the Malaysian Palm Oil Board (MPOB) Research Stations (MPOB/UKM, Selangor and Kluang, Johor in Malaysia). Various tissues, including spear leaf, mature leaf, male inflorescence, female inflorescence, root, whole fruit, mesocarp and kernel were included in this study. Whole fruits were harvested at two developmental stages ( 8 and 15 WAA). During sampling, whole fruits (epicarp, mesocarp, endocarp and kernel) were chopped into small pieces. For mesocarp and kernel samples, these tissues were dissected and separated from oil palm fruits. All samples with one biological replicate were immediately frozen in liquid nitrogen and stored at $-80^{\circ} \mathrm{C}$ until further use.

\section{Total RNA Extraction (modified CTAB-LiCl method with addition of phenol)}

Total RNA extraction method for oil palm was adapted from Sangha et al. (2010). The extraction buffer contained 2\% (w/v) CTAB, 2\% (w/v) polyvinylpyrrolidone (PVP-40), $100 \mathrm{mM}$ Tris- $\mathrm{HCl}$ [pH 8.0], 25 mM EDTA [pH8.0], 2 M sodium chloride $(\mathrm{NaCl})$ and $\mathrm{RNase}$-free water (for final volume makeup) was prepared and pre-heated in $65^{\circ} \mathrm{C}$ water bath. Frozen tissue (approximately $1 \mathrm{~g}$ weight per sample) was ground into fine powder in liquid nitrogen using pre-chilled mortar and pestle. A total of $2 \%(\mathrm{w} / \mathrm{v}) \quad \beta$-mercaptoethanol was added just before use to the pre-heated extraction buffer and 
mixed well. The ground powder was transferred immediately into $15 \mathrm{ml}$ of pre-heated extraction buffer in a glass beaker and mix thoroughly. The mixture was transferred to a polypropylene tube and homogenised by vortexing for $10 \mathrm{~min}$. The polypropylene tube was subsequently incubated at $65^{\circ} \mathrm{C}$ water bath for 30 min with vigorous vortexing every 10 min during the incubation period.

Subsequently, an equal volume of phenol: chloroform: isoamylalcohol (25:24:1; phenol equilibrated with Tris- $\mathrm{HCl}, \mathrm{pH} 8.0$ ) was added to the mixture and vortexed vigorously for $10 \mathrm{~min}$. The mixture was centrifuged at $11950 \times \mathrm{g}$ for 20 min at $4^{\circ} \mathrm{C}$ using Sorvall RC 6 Plus Superspeed Centrifuge (Thermo Fisher Scientific, USA). The clear upper aqueous phase was transferred into another polypropylene tube. An equal volume of chloroform:isoamylalcohol (24:1) was added and mixed by vortexing for $10 \mathrm{~min}$. The mixture was centrifuged at $11950 \times \mathrm{g}$ for $10 \mathrm{~min}$ at $4^{\circ} \mathrm{C}$.

After centrifugation, the upper aqueous phase was transferred into a new polypropylene tube. The aqueous supernatant was ethanol precipitated with 0.1 volume of ice-cold $3 \mathrm{M}$ sodium acetate $(\mathrm{pH}$ 4.8 ) and 2 volume of ice-cold absolute ethanol. The reaction was gently mixed by inverting the tube and was kept at $-80^{\circ} \mathrm{C}$ for $1 \mathrm{hr}$. Nucleic acids pellet was collected by centrifugation at $11950 \times \mathrm{g}$ for $30 \mathrm{~min}$ at $4^{\circ} \mathrm{C}$ and the supernatant was discarded. The pellet was rinsed with $12 \mathrm{ml}$ of ice-cold $70 \%$ ethanol and followed by centrifugation at $11950 \times \mathrm{g}$ for $30 \mathrm{~min}$ at $4^{\circ} \mathrm{C}$. The supernatant was discarded and the pellet was dried partially on ice for $10 \mathrm{~min}$. The pellet containing nucleic acids was re-suspended in $6 \mathrm{ml}$ of ice-cold RNase-free water.

To selectively precipitate RNA, $2 \mathrm{M}$ of ice-cold $\mathrm{LiCl}$ was added and incubated overnight at $4^{\circ} \mathrm{C}$. Total RNA was pelleted by centrifugation at $11950 \times \mathrm{g}$ for $30 \mathrm{~min}$ at $4^{\circ} \mathrm{C}$ and the supernatant was discarded. The pellet was dried partially on ice for $10 \mathrm{~min}$ and re-suspended in $3 \mathrm{ml}$ of ice-cold RNase-free water. The total RNA pellet was precipitated again with the addition of $2 \mathrm{M}$ of ice-cold $\mathrm{LiCl}$ and stored at $-20^{\circ} \mathrm{C}$ for $2 \mathrm{hr}$. The total RNA was recovered through centrifugation at $11950 \times \mathrm{g}$ for $30 \mathrm{~min}$ at $4^{\circ} \mathrm{C}$. Then, the supernatant was discarded and the pellet was dried partially on ice for $10 \mathrm{~min}$ and dissolved in $200 \mu$ lice-cold RNase-free water. The total RNA was transferred into a microcentrifuge tube and stored at $-80^{\circ} \mathrm{C}$.

\section{Assessment of Total RNA Quantity and Purity}

The concentration and purity of the total RNA was estimated using NanoDrop ND-1000 spectrophotometer (NanoDrop Technologies, USA). The total RNA was subjected to purification using RNeasy Mini kit (Qiagen, USA). In order to minimise genomic DNA contamination that could interfere with gene expression studies, on-column DNase I digestion was also performed according to the manufacturer's instructions. The integrity of the purified total RNA was determined on an Agilent 2100 Bioanalyser using a RNA 6000 Nano LabChip (Agilent Technologies, USA).

\section{Reverse Transcription Quantitative Real-time PCR (RT-qPCR)}

First strand cDNA synthesis was performed with $2 \mu \mathrm{g}$ of purified total RNA using HighCapacity cDNA Reverse Transcription Kit (Applied Biosystems, USA) according to the manufacturer's instructions. The synthesised cDNA was used as template for RT-qPCR. The RT-qPCR was performed with KAPA SYBR Fast qPCR Kit (KAPA Biosystems, USA) using the Mastercycler ep realplex (Eppendorf, Germany) as described by Chan et al. (2014). Each reverse transcription (RT) reaction was performed in triplicate and included two negative controls such as no reverse transcription (NRT) and no template control (NTC). Two published reference genes (PD00569 and pOP-EA01332) and a gene of interest (PD00088) were used for gene expression analysis (Chan et al., 2014). The primers used in RTqPCR are listed in Table 1.

The cycle threshold $(\mathrm{Ct})$ values were retrieved using Realplex software version 2.2 (Eppendorf,

TABLE 1. PRIMER SEQUENCES FOR RT-qPCR

\begin{tabular}{lllcc}
\hline $\begin{array}{l}\text { Gene name } \\
\text { (abbreviation) }\end{array}$ & Genebank ID & \multicolumn{1}{c}{ Primer sequences $\left(5^{\prime}-3^{\prime}\right)$} & $\begin{array}{c}\text { Amplicon } \\
\text { length }(\mathbf{b p})\end{array}$ & $\begin{array}{c}\text { Annealing } \\
\text { temperature }\left({ }^{\circ} \mathbf{C}\right)\end{array}$ \\
\hline $\begin{array}{c}\text { Manganese superoxide } \\
\text { dismutase (PD00569) }\end{array}$ & EL682210.1 & $\begin{array}{l}\text { Forward: CACCACCAGACGTACATCACAAA } \\
\text { Reverse: GATATGACCTCCGCCATTGAACT }\end{array}$ & 129 & 60 \\
$\begin{array}{c}\text { Predicted protein IFH-1 } \\
\text { like (pOP-EA01332) }\end{array}$ & EY406625.1 & $\begin{array}{l}\text { Forward: AAACGAAGGTACGGCAAGTACAAG } \\
\text { Reverse: CTTAGCACATGCAGAGCAGATGTT }\end{array}$ & 111 & 60 \\
$\begin{array}{c}\text { Putative ethylene- } \\
\text { responsive transcription } \\
\text { factor-3 like (PD00088) }\end{array}$ & $\begin{array}{l}105050183 \\
\text { and }\end{array}$ & $\begin{array}{l}\text { Forward: CGTGGAAGAAGACGAGGAAATG } \\
\text { Reverse: CAGGTACCCGAAGTTCGTCTTG }\end{array}$ & 122 & 60 \\
\hline
\end{tabular}

Note: RT-qPCR - reverse transcription quantitative real-time polymerase chain reaction. 
Germany) and accepted for further analysis if the standard deviation among replicates were less than 0.3. The PCR amplification efficiency of the primer was determined using LinRegPCR (Ruijter et al., 2009). The normalised expression level (R) of the PD00088 gene was calculated based on the mathematical model described by Pfaffl (2001). The specificity of each primers by RT-qPCR was investigated using melting curve and the PCR products were examined using $1 \%$ agarose gel.

\section{RESULTS AND DISCUSSION}

\section{Modified CTAB-LiCl Method with Addition of Phenol is Suitable for Total RNA Extraction from Various Oil Palm Tissues}

Using the described method, high quality total RNA was extracted from all tested oil palm tissues. The CTAB-based method is widely used to extract total RNA from plant tissues. Extraction of total RNA from whole fruit in oil palm was initiated for studies related to fruit colour. The total RNA from nigrescens and virescens whole fruits were used for transcriptome sequencing (Singh et al., 2014). However, oil palm whole fruit is rich in polysaccharides, polyphenols and other secondary metabolites. Conventional CTAB method failed to extract total RNA from whole fruit at mature stage. Furthermore, when the method was used to extract total RNA from kernel at 15 WAA, it was observed that the absorbance ratio for $\mathrm{A}_{260} / \mathrm{A}_{230}(0.45)$ and total yield $\left(0.9 \mu \mathrm{g} \mathrm{g}^{-1}\right.$ fresh weight) were very low.

In the modified method, application of phenol: chloroform:isoamylalcohol $(25: 24: 1)$ as extraction reagents was found to be more efficient than using chloroform:isoamylalcohol (24:1) alone. Addition of phenol equilibrated with Tris- $\mathrm{HCl}$ [pH8.0] in chloroform:isoamylalcohol (24:1) purification step enabled the removal of proteins more effectively and assisted in the inactivation of RNase (Zhang et al., 2018). The modified method also included a $\mathrm{LiCl}$ precipitation step which is generally used for total RNA precipitation. Due to the high ionic strength of $\mathrm{LiCl}$, large RNA (rRNA and mRNA) are insoluble in the $\mathrm{LiCl}$ containing solution (Sambrook and Russell, 2001). Hence, it helps to separate total RNA from other contaminants such as DNA, protein or carbohydrate (Smart and Roden, 2010). Carpenter and Simon (1998) reported that good quality total RNA was obtained when resuspension, incubation and precipitation in $\mathrm{LiCl}$ was repeated. This was found to be applicable in other plant species such as mulberry (Sajeevan et al., 2014) and loquat (MoranteCarriel et al., 2014). In our study, application of repeated $\mathrm{LiCl}$ precipitation step has also resulted in the extraction of good quality total RNA.

The total RNA yield obtained from this method ranged from 60.31 to $373.97 \mu \mathrm{g} \mathrm{g}^{-1}$ fresh weight (Table 2). The highest total RNA yield was observed in male inflorescence and the lowest total RNA yield was obtained from kernel at 15 WAA. To evaluate purity of total RNA, the spectrophotometric absorbance at 230, 260 and $280 \mathrm{~nm}$ were obtained. The $\mathrm{A}_{260} / \mathrm{A}_{280}$ ratio was higher than 2.00 in all the tested samples, ranging from 2.04 to 2.14 , indicating that minimal protein contamination was present in the total RNA samples. The $A_{260} / A_{230}$ ratio was above 1.83, suggesting that the total RNA samples had low polysaccharide contamination. Previous study has reported the ratios of $\mathrm{A}_{260} / \mathrm{A}_{280}$ and $\mathrm{A}_{260} / \mathrm{A}_{230}$ values greater than 1.8, which showed the absence of protein and other organic compounds (Claros and Canovas, 1999).

The integrity of the total RNA were examined using Agilent 2100 Bioanalyser and the electropherogram showed the presence of intact ribosomal bands of $18 \mathrm{~S}$ and $25 \mathrm{~S}$ (Figure 1). In addition, the thickness of the 25S was approximately twice of 18S. The results indicated that minimum or no total RNA degradation occurred. However,

TABLE 2. YIELD AND PURITY OF TOTAL RNA EXTRACTED FROM VARIOUS OIL PALM TISSUES

\begin{tabular}{lcccc}
\hline Tissue used & $\mathbf{A}_{\mathbf{2 6 0}} / \mathbf{A}_{\mathbf{2 8 0}}$ & $\mathbf{A}_{\mathbf{2 6 0}} / \mathbf{A}_{\mathbf{2 3 0}}$ & RIN & Yield $\left(\mu \mathbf{g} \mathbf{g}^{-1}\right)$ \\
\hline Spear leaf & $2.14 \pm 0.01$ & $1.83 \pm 0.01$ & 8.1 & $85.49 \pm 0.49$ \\
Mature leaf & $2.12 \pm 0.02$ & $2.27 \pm 0.01$ & 7.4 & $91.39 \pm 0.47$ \\
Male inflorescence & $2.12 \pm 0.00$ & $2.27 \pm 0.01$ & 9.5 & $373.97 \pm 0.78$ \\
Female inflorescence & $2.12 \pm 0.01$ & $2.26 \pm 0.01$ & 8.5 & $246.77 \pm 0.16$ \\
Whole fruit_8 WAA & $2.07 \pm 0.02$ & $2.23 \pm 0.01$ & 7.5 & $154.37 \pm 0.78$ \\
Whole fruit_15 WAA & $2.04 \pm 0.02$ & $2.11 \pm 0.02$ & 8.3 & $76.97 \pm 0.09$ \\
Mesocarp_8 WAA & $2.13 \pm 0.01$ & $1.89 \pm 0.01$ & 8.4 & $181.00 \pm 1.20$ \\
Mesocarp_15 WAA & $2.13 \pm 0.01$ & $2.12 \pm 0.01$ & 8.5 & $115.79 \pm 0.71$ \\
Kernel_8 WAA & $2.05 \pm 0.00$ & $2.02 \pm 0.01$ & 7.5 & $89.95 \pm 1.01$ \\
Kernel_15 WAA & $2.10 \pm 0.02$ & $2.22 \pm 0.01$ & 8.9 & $60.31 \pm 0.39$ \\
Root & $2.13 \pm 0.01$ & $2.22 \pm 0.02$ & $64.07 \pm 0.26$ \\
\hline
\end{tabular}

Note: The absorbance readings were measured three times. RNA - ribonucleic acid.

Values are means \pm standard deviation $(n=3)$. RIN - RNA integrity number.

WAA - weeks after anthesis. 
some faint bands were observed in total RNA extracted from spear leaf (non-green tissue, sample 1) and mature leaf (green tissue, sample 2). This observation seems to be consistent with that of Claros and Canovas (1999) who showed that faint bands (small rRNA molecules from chloroplast and mitochondria) were observed in spinach leaves. The RNA integrity number (RIN) values observed in this study ranged from 7.4 to 9.0. A RIN values exceeded 7.0 , suggesting that the total RNA is suitable for high stringency application such as RT-qPCR (Udvardi et al., 2008) and next generation sequencing (Yockteng et al., 2013). These results showed the successful isolation of high quality total RNA from various oil palm tissues.

\section{Expression Profiling of PD00088 across Various Tissues of Oil Palm}

The quality of the total RNA was further examined by RT-qPCR. All the total RNA samples extracted from spear leaf, mature leaf, male inflorescence, female inflorescence, whole fruit (8 WAA and 15 WAA), mesocarp (8 WAA and

(a)

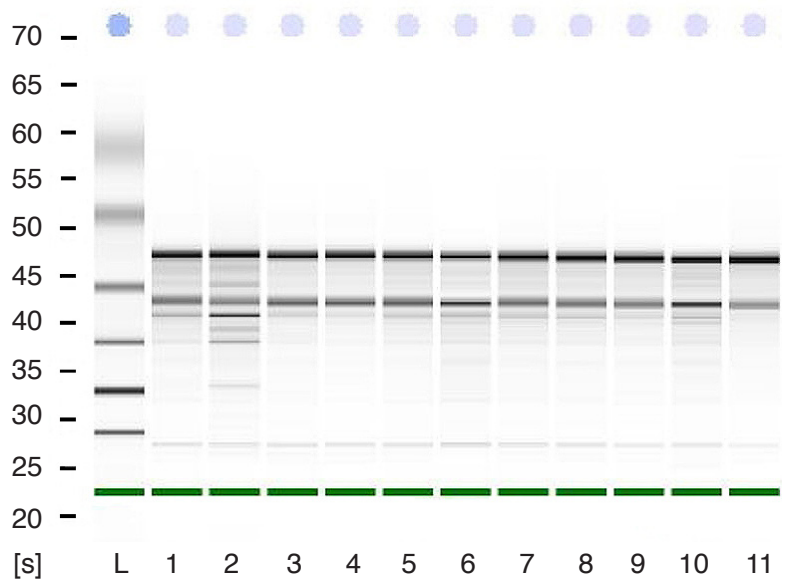

Whole fruit_8WAA

(b) $[\mathrm{FU}]$
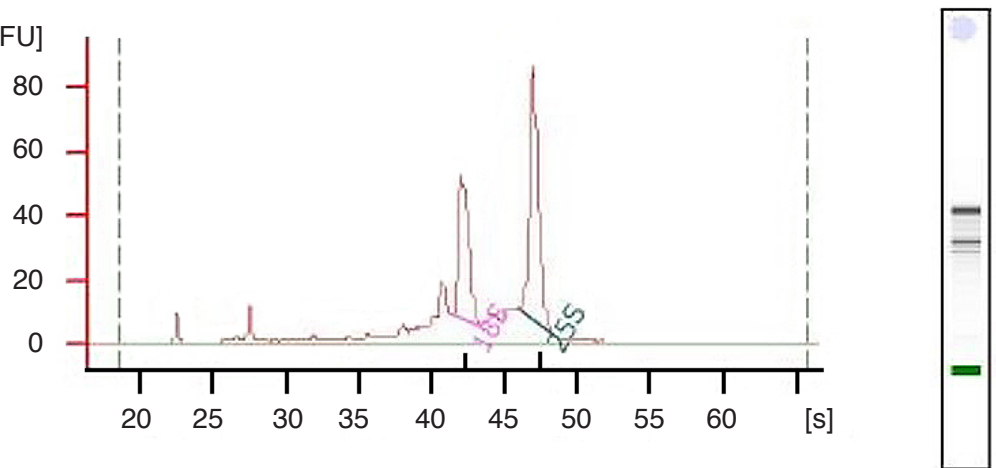

(c)
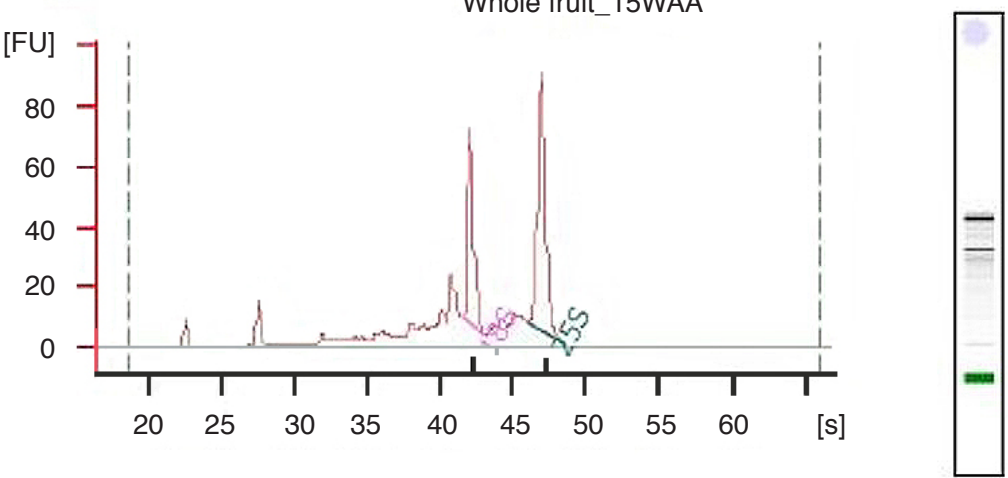

Figure 1. Total ribonucleic acid (RNA) samples investigated on an Agilent 2100 Bioanalyser RNA Nano LabChip. (a) Total RNA extracted from various oil palm tissues: 1) spear leaf, 2) mature leaf, 3) male inflorescence, 4) female inflorescence, 5) whole fruit_8 weeks after anthesis (WAA), 6) whole fruit_15 WAA, 7) mesocarp_8 WAA, 8) mesocarp_15 WAA, 9) kernel_8 WAA, 10) kernel_15 WAA, 11) root and L) Ambion ${ }^{\circledR}$ RNA 6000 Ladder. An electropherogram of $(b)$ whole fruit_8 WAA and $(c)$ whole fruit_15 WAA are provided as an example. 
15 WAA), kernel (8 WAA and 15 WAA) and root were successfully amplified using a target gene (PD00088) and two reference genes (PD00569 and pOP-EA01332) as shown in Figure 2. Moreover, a single peak was observed in the melting curve and a fragment was obtained in $1 \%$ agarose gel from each of the selected gene. These results indicated the specificity of the amplified PCR products.

The expression levels of an ethylene-responsive transcription factor-3 like (PD00088) gene were normalised with two reference genes, PD00569 and pOP-EA01332. The PCR amplification efficiencies for each gene were in the range of 1.834 to 1.891 .
Quantitative expression investigation of PD00088 through RT-qPCR confirmed their differential expression in various oil palm tissues as shown in Figure 3. The spear leaf was used as calibrator for RT-qPCR experiment. This calibrator sample was a reference point for the relative quantification of the PD00088 expression level which was set at 1.0. Therefore, the normalised expression level of PD00088 in each sample is indicated as a comparison to the calibrator value. The PD00088 was expressed in all the tested tissues and showed higher expression in whole fruit (15 WAA) followed by root. The lower expression levels of the gene were observed in male (a)

$\begin{array}{lllllllllll}1 & 2 & 3 & 4 & 5 & 6 & 7 & 8 & 9 & 10 & 11\end{array}$
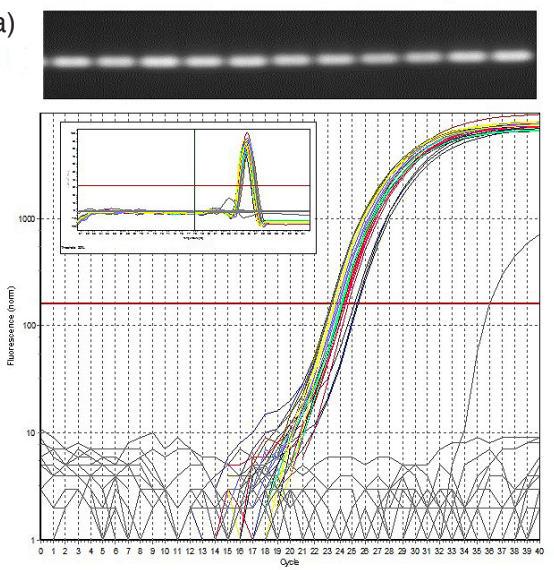

$\begin{array}{lllllllllll}1 & 2 & 3 & 4 & 5 & 6 & 7 & 8 & 9 & 10 & 11\end{array}$

(b)
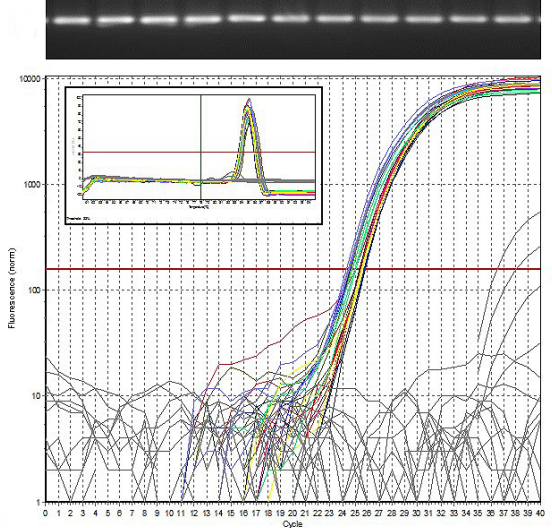

$\begin{array}{lllllllllll}1 & 2 & 3 & 4 & 5 & 6 & 7 & 8 & 9 & 10 & 11\end{array}$

(c)
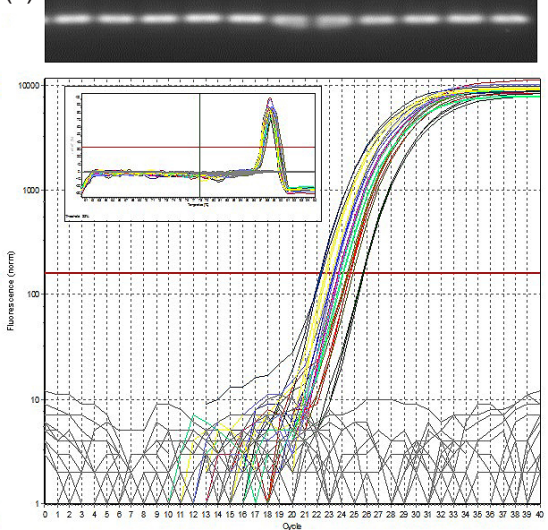

Note: WAA - weeks after anthesis.

Figure 2. Reverse transcription quantitative real-time polymerase chain reaction (RT-qPCR) amplification products. a) Ethylene-responsive transcription factor-3 like (PD00088) and two reference genes b) PD00569 and c) pOP-EA01332 were amplified across total ribonucleic acid (RNA) samples extracted from various oil palm tissues using modified cetyltrimethylammonium bromide-lithium chloride (CTAB-LiCl) method with addition of phenol. The cDNA was synthesised from 1) spear leaf, 2) mature leaf, 3) male inflorescence, 4) female inflorescence, 5) mesocarp_8 WAA, 6) mesocarp_15 WAA, 7) root, 8) kernel_8 WAA, 9) kernel_15 WAA, 10) whole fruit_8 WAA and 11) whole fruit_15 WAA. No products were amplified for no reverse transcription (NRT) and no template control (NTC).

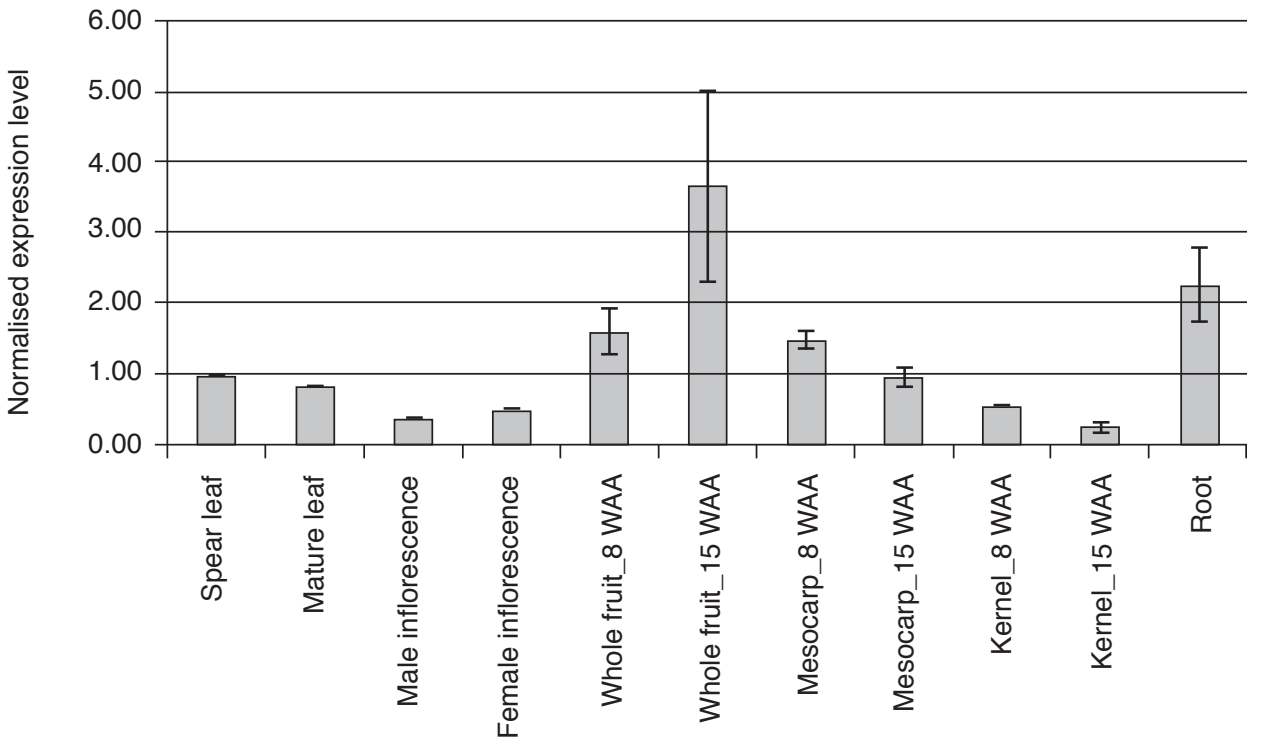

Figure 3. Analysis of PD00088 gene expression in various oil palm tissues. 
inflorescence, female inflorescence and kernel (8 WAA and 15 WAA). A previous study by Osorio et al. (2012) showed the up-regulation of this gene during the fruit ripening in pepper. Furthermore, overexpression of the Glycine max ERF3 in transgenic tobacco resulted in enhanced resistance to bacterial and fungal pathogens as well as salt and drought tolerance (Zhang et al., 2009). All these data suggest that ethylene-responsive transcription factor-3 like could play an important role during fruit ripening, biotic and abiotic stress responses. Further studies would likely provide a better understanding of the expression and regulation of this gene in oil palm.

\section{CONCLUSION}

A reliable method for total RNA extraction from various oil palm tissues especially whole fruit at two different developmental stages (8 WAA and 15 WAA) was successfully developed. The method produced high quality and intact total RNA. Effectiveness of this method was confirmed by spectrophotometric analysis, Bioanalyser and RTqPCR. These results demonstrated that the extracted total RNA is suitable for gene expression analysis using RT-qPCR.

\section{ACKNOWLEDGEMENT}

The authors would like to thank the DirectorGeneral of MPOB for permission to publish this article. We would also like to thank all the staff in Molecular Genetic Group, Advanced Breeding and Biotechnology Centre, MPOB for their technical assistance during the sampling of oil palm fruits. This work was funded by DNA Chip Technology Programme (R000999000).

\section{REFERENCES}

Amanda, U D and Cartealy, I C (2015). Total RNA isolation from the mesocarp of oil palm (Elaeis guineensis Jacq. var. Tenera) fruits. Prosiding Seminar National Masyarakat Biodiversitas Indonesia, 1: 171176.

Bustin, S A and Nolan, T (2004). Pitfalls of quantitative real-time reverse transcription polymerase chain reaction. J. Biomolecular Techniques, 15: 155-166.

Bustin, S A; Benes, V; Garson, J A; Hellemans, J; Huggett, J; Kubista, M; Mueller, R; Nolan, T; Pfaffl, M W; Shipley, G L; Vandesompele, J and Wittwer, C T (2009). The MIQE guidelines: Minimum information for publication of quantitative real-time PCR experiments. Clinical Chemistry, 55: 611-622.
Carpenter, C D and Simon, A E (1998). Preparation of RNA. Method in Molecular Biology, Arabidopsis Protocols (Martinez-Zapater, J and Salinas J eds.). Vol. 82. Humana Press, Totowa, USA. p. 85-89.

Chai, S-K; Namasivayam, P; Ho, C-L; Norazlin, A A; Ong-Abdullah, M and Ooi, S-E (2016). RNA from fresh frozen cryosections of oil palm inflorescences is superior to FFPE sections. J. Oil Palm Res. Vol. 28: 154-160.

Chan, P-L; Rose, R J; Abdul Munir, A M; Zamri, Z; Low, E-T L; Ooi, L C-L; Ooi, S-E; Suzaini, Y and Singh, R (2014). Evaluation of reference genes for quantitative real-time PCR in oil palm elite planting materials propagated by tissue culture. PLOS ONE, 9: e99774.

Chang, S; Puryear, J and Cairney, J (1993). A simple and efficient method for isolating RNA from pine trees. Plant Molecular Biology Reporters, 11: 113-116.

Claros, M G and Canovas, F M (1999). RNA isolation from plant tissues: A practical experience for biological undergraduates. Biochemical Education, 27: 110-113.

Djami-Tchatchou, A T and Straker, C J (2012). The isolation of high quality RNA from the fruit of avocado (Persea Americana Mill.). South African J. Botany, 78: 44-46.

Dussert, S; Guerin, C; Andersson, M; Joet, T; Tranbarger, T J; Pizot, M; Sarah, G; Omore, A; Durand-Gasselin, T and Marcillo, F (2013). Comparative transcriptome analysis of three oil palm fruit and seed tissues that differ in oil content and fatty acid composition. Plant Physiology, 162: 1337-1358.

Fleige, S and Pfaffl, M W (2006). RNA integrity and the effect on the real-time qRT-PCR performance. Molecular Aspects of Medicine, 27: 126-139.

Gachon, C; Mingam, A and Charrier, B (2004). Real-time PCR: What relevance to plant studies? J. Experiment Botany, 55: 1445-1454.

Habib, S H; Saud, H M and Kausar, H (2014). Efficient oil palm total RNA extraction with a total RNA extraction kit. Genetics and Molecular Research, 13: 2359-2367.

Jin, J; Sun, Y; Qu, J; Rahmad, S; Lim, C-H; Yuzer, A; Nurestyabte, R; Antonius, S; Yue, G; Wong, L; Chua, $\mathrm{N}-\mathrm{H}$ and $\mathrm{Ye}, \mathrm{J}$ (2017). Transcriptome and functional analysis reveals hybrid vigor for oil biosynthesis in oil palm. Scientific Reports, 7: 439. 
Kok, S Y; Namasivayam, P; Ee, G C L and OngAbdullah, M (2013). Biochemical characterisation during seed development of oil palm (Elaeis guineensis). J. Plant Research, 126: 539-547.

Kushairi, A; Loh, S K; Azman, I; Hishamuddin, E; Ong-Abdullah, M; Mohd Noor Izuddin, Z B; Razmah, G; Sundram, S and Parveez, G K A (2018). Oil palm economic performance in Malaysia R\&D progress in 2017. J. Oil Palm Res. Vol. 30(2): 163-195.

Laksana, C and Chanprame, S (2015). A simple and rapid method for RNA extraction from young and mature leaves of oil palm (Elaeis guineensis Jacq.). J. ISSAAS, 21: 96-106.

Low, E-T L; Chan, P L; Ooi, L C-L; Rahim, R A; Shahrul, S; Cheah, S C; Ho, C L and Singh, R (2009). Protocol optimization and quality assessment of oil palm cDNA microarray experiments. Proc. of the PIPOC 2009 International Palm Oil Congress Agriculture, Biotechnology \& Sustainability Conference. MPOB, Bangi. p. 1313-1330.

Morante-Carriel, J; Selles-Marchart, S; MartinezMarquez, A; Martinez-Esteso, M J; Luque, I and BruMartinez, R (2014). RNA isolation from loquat and other recalcitrant woody plants with high quality and yield. Analytical Biochemistry, 452: 46-53.

Muoki, R C; Paul, A; Kumari, A; Singh, K and Kumar, S (2012). An improved protocol for the isolation of RNA from roots of tea [Camellia sinensis (L.) O. Kuntze]. Molecular Biotechnology, 52: 82-88.

Osorio, S; Alba, R; Nikoloski, Z; Kochevenko, A; Fernie, A R and Giovannoni, J J (2012). Integrative comparative analyses of transcript and metabolite profiles from pepper and tomato ripening and development stages uncovers species patterns of network regulatory behavior. Plant Physiology, 159: 1713-1729.

Pfaffl, M W (2001). A new mathematical model for relative quantification in real-time RT-PCR. Nucleic Acids Research, 18: e45.

Ruijter, J M; Ramakers, C; Hoogaars, W M; Karlen, Y; Bakker, O; Van Den Hoff, M J and Moorman, A F (2009). Amplification efficiency: Linking baseline and bias in the analysis of quantitative PCR data. Nucleic Acids Research, 37: e45.

Sajeevan, R S; Shivanna, M B and Nataraja, K N (2014). An efficient protocol for total RNA isolation from healthy and stressed tissues of mulberry (Morus sp.) and other species. American J. Plant Sciences, 5: 2057-2065.
Sambanthamurthi, R; Sundram, K and Tan, Y-A (2000). Chemistry and biochemistry of palm oil. Progress in Lipid Research, 39: 507-558.

Sambrook, J and Russell, D W (2001). Commonly used techniques in molecular cloning. Molecular Cloning: A Laboratory Manual. Cold Spring Harbor Laboratory Press, Cold Spring Harbor, New York. p. A8.1-A8.55.

Sangha, J S; Gu, K; Kaur, J and Yin, Z (2010). An improved method for RNA isolation and cDNA library construction from immature seeds of Jatropha curcas L. BMC Research Notes, 3: 126.

Shaharuddin, N A and Parveez, G K (2003). Isolation of RNA from oil palm tissues for screening of constitutively expressing genes in oil palm. Proc. of the PIPOC 2003 International Palm Oil Congress Agriculture, Biotechnology \& Sustainability Conference. MPOB, Bangi. p. 844-851.

Singh, R; Low, E-T L; Ooi, L C-L; Ong-Abdullah, M; Nookiah, R; Ting, N-C; Marhalil, M; Chan, P-L; Maizura, I; Mohd Arif, A M; Jayanthi, N; Chan, K-L; Rozana, R; Mohd Amin, H; Norazah, A; Budiman, M A; Lakey, N; Bacher, B; Van Brunt, A; Wang, C; Hogan, M; He, D; Macdonald, J D; Smith, S W; Ordway, J M; Robert A Martienssen, R A and Sambanthamurthi, R (2014). The oil palm VIRESCENS gene controls fruit colour and encodes a R2R3-MYB. Nature Communications, 5: 4106.

Smart, M and Roden, L C (2010). A small-scale RNA isolation protocol useful for high-throughput extractions from recalcitrant plant. South African J. Botany, 76: 375-379.

Tong, Z; Qu, S; Zhang, J; Wang, F; Tao, J; Gao, Z and Zhang, Z (2012). A modified protocol for RNA extraction from different peach tissues suitable for gene isolation and real-time PCR analysis. Molecular Biotechnology, 50: 229-236.

Tranbarger, T J; Dussert, S; Joet, T; Argout, X; Summo, M; Champion, A; Cros, D; Omore, A; Nouy, B and Morcillo, F (2011). Regulatory mechanisms underlying oil palm fruit mesocarp maturation, ripening and functional specialization in lipid and carotenoid metabolism. Plant Physiology, 156: 564-584.

Udvardi, M K; Czechowski, T and Scheible, W-R (2008). Eleven golden rules of quantitative RT-PCR. Plant Cell, 20: 1736-1737.

Umi Salamah, R; Sambanthamurthi, R; Omar, A R; Ahmad Parveez, G K; Mohamad Arif, A M; Abrizah, O; Abdul Masani, Y; Cheah, S C; Sharifah Sharul Rabiah, S A; Siti Nor Akmar, A and Mohd Basri, 
W (2012). The isolation and characterisation of oil palm (Elaeis guineensis Jacq.) $\beta$-ketoacyl-acyl carrier protein (ACP) synthase (KAS) II cDNA. J. Oil Palm Res. Vol. 24: 1480-1491.

Wong, Y C; Kwong, Q B; Lee, H L; Ong, C K; Mayes, S; Chew, F T; Appleton, D R and Kulaveerasingam, $H$ (2014). Expression comparison of oil biosynthesis genes in oil palm mesocarp tissue using custom array. Microarrays, 3: 263-81.

Yockteng, R; Almeida, A M R; Yee, S; Andre, T; Hill, C and Specht, C D (2013). A method for extracting high-quality RNA from diverse plants for next-generation sequencing and gene expression analyses. Applications in Plant Sciences, 1: 1300070.

Zhang, G; Chen, M; Li, L; Xu, Z; Chen, X; Guo, J and Ma, Y (2009). Overexpression of the soybean GmERF3 gene, an AP2/ERF type transcription factor for increased tolerances to salt, drought, and diseases in transgenic tobacco. J. Experimental Botany, 60: 3781-3796.

Zhang, N; Yu, D and Zhu, X (2018). RNA isolation from plant tissues: A hands-on laboratory experimental experience for undergraduates. Biochemistry and Molecular Biology Education, 46(3): 253-261. 